\title{
Trypsin activates pancreatic duct epithelial cell ion channels through proteinase-activated receptor-2
}

\author{
Toan D. Nguyen, ${ }^{1}$ Mark W. Moody, ${ }^{1}$ Martin Steinhoff, ${ }^{2}$ Charles Okolo, ${ }^{1}$ \\ Duk-Su Koh, ${ }^{3}$ and Nigel W. Bunnett ${ }^{2}$

\begin{abstract}
${ }^{1}$ Department of Medicine, University of Washington and Veterans Affairs Puget Sound Health Care System, Seattle, Washington 98108, USA

${ }^{2}$ Departments of Surgery and Physiology, University of California, San Francisco, California 94143, USA

${ }^{3}$ Department of Physiology and Biophysics, University of Washington, Seattle, Washington 98195, USA
\end{abstract}

Address correspondence to: Toan D. Nguyen, GI Section (111 GI), Veterans Affairs Medical Center, 1660 S. Columbian Way, Seattle, Washington 98108, USA. Phone: (206) 764-2285; Fax: (206) 764-2232; E-mail: t1nguyen@u.washington.edu

Received for publication December 16, 1997, and accepted in revised form November 17, 1998.

\begin{abstract}
Proteinase-activated receptor-2 (PAR-2) is a G protein-coupled receptor that is cleaved by trypsin within the $\mathrm{NH}_{2}$-terminus, exposing a tethered ligand that binds and activates the receptor. We examined the secretory effects of trypsin, mediated through PAR-2, on well-differentiated nontransformed dog pancreatic duct epithelial cells (PDEC). Trypsin and activating peptide (AP or SLIGRL-NH ${ }_{2}$, corresponding to the PAR-2 tethered ligand) stimulated both an ${ }^{125} \mathrm{I}^{-}$efflux inhibited by $\mathrm{Ca}^{2+}$-activated $\mathrm{Cl}^{-}$channel inhibitors and a ${ }^{86} \mathrm{Rb}^{+}$efflux inhibited by a $\mathrm{Ca}^{2+}$-activated $\mathrm{K}^{+}$channel inhibitor. The reverse peptide (LRGILS-NH ${ }_{2}$ ) and inhibited trypsin were inactive. Thrombin had no effect, suggesting absence of PAR1, PAR-3, or PAR-4. In Ussing chambers, trypsin and AP stimulated a short-circuit current from the basolateral, but not apical, surface of PDEC monolayers. In monolayers permeabilized basolaterally or apically with nystatin, AP activated apical $\mathrm{Cl}^{-}$and basolateral $\mathrm{K}^{+}$conductances. PAR-2 agonists increased $\left[\mathrm{Ca}^{2+}\right]_{\mathrm{i}}$ in PDEC, and the calcium chelator BAPTA inhibited the secretory effects of AP. PAR-2 expression on dog pancreatic ducts and PDEC was verified by immunofluorescence. Thus, trypsin interacts with basolateral PAR-2 to increase $\left[\mathrm{Ca}^{2+}\right]_{\mathrm{i}}$ and activate ion channels in PDEC. In pancreatitis, when trypsinogen is prematurely activated, PAR-2-mediated ductal secretion may promote clearance of toxins and debris.
\end{abstract}

J. Clin. Invest. 103:261-269 (1999).

\section{Introduction}

Proteinase-activated receptor-2 (PAR-2) is the second member of the new family of $G$ protein-coupled receptors that are activated by proteolysis rather than binding to a soluble ligand (reviewed in ref. 1). PAR-1, PAR-3, and PAR-4 are receptors for thrombin (2-5); PAR-2 is a receptor for pancreatic trypsin and mast cell tryptase $(6,7)$. Trypsin and tryptase cleave within the extracellular $\mathrm{NH}_{2}-$ terminus of PAR-2 at SKGR $\downarrow$ SLIGRL, yielding a tethered ligand (SLIGRL) that binds to and activates the cleaved receptor. Synthetic peptides corresponding to this tethered ligand domain selectively activate PAR-2 without proteolysis. They are thus valuable reagents for studing receptor function without the use of proteases, which may cleave other proteins.

The gene encoding PAR-2 has been cloned in humans, and PAR-2 has been found to be highly expressed in the pancreas and kidney as well as intestine, liver, prostate, heart, lung, and trachea (8). High pancreatic expression is supported by abundant PAR-2 expression in several cell lines derived from pancreatic acinar and duct cells. However, although the tissue distribution of PAR-2 has been examined, its precise cellular localization, ligands, and physiological function are unknown for most tissues.

The very high level of PAR-2 expression in the pancreas is intriguing, as trypsin, the protease that cleaves and triggers PAR-2 with highest potency and efficacy, is syn- thesized and secreted by pancreatic acinar cells. Although trypsin is traditionally considered as a digestive enzyme, we have recently reported (9) that physiological concentrations of trypsin in the intestinal lumen cleave and activate PAR-2 at the apical membrane of enterocytes, suggesting that trypsin also acts as a signaling molecule that specifically targets cells through PAR2. It is therefore possible that trypsin also activates PAR2 in the pancreas and thereby regulates pancreatic function. However, trypsin is mostly secreted as its inactive zymogen precursor, trypsinogen, which is inactive until it is cleaved by enterokinase in the intestinal lumen. Although small amounts of active trypsin are formed within the pancreas under normal circumstances, trypsin is prematurely autoactivated within the inflamed pancreas and is believed to contribute to pancreatitis (10). Indeed, the genetic defects of hereditary pancreatitis are amino acid mutations of trypsin that render it resistant to degradation following premature autoactivation $(11,12)$. Therefore, trypsin may cleave and activate PAR-2 within the inflamed pancreas. A role for PAR2 in inflammation is also supported by the finding that tryptase, a prominent component of secretory granules of most subsets of human mast cells that is released upon degranulation, also activates PAR-2 $(7,13)$. Tryptase may also trigger PAR-2 in the pancreas during inflammation, when mast cells are present (Nguyen, 
T.D., et al., unpublished observations). However, the localization of PAR-2 in the exocrine pancreas and the consequences of receptor activation are unknown.

The principal cell types within the exocrine pancreas are acinar cells, which secrete digestive enzymes, and pancreatic duct epithelial cells (PDEC), which secrete fluid and electrolytes, mainly bicarbonate. Recently, Oda et al. developed methods to isolate and culture dog PDEC that are nontransformed, well-differentiated, and polarized, and which retain many of the characteristics of PDEC, such as mucin secretion (14) and the presence of cAMP- and $\mathrm{Ca}^{2+}$ activated $\mathrm{Cl}^{-}$channels (15), and $\mathrm{Ca}^{2+}$-activated $\mathrm{K}^{+}$channels (16). They are thus ideally suited for detailed examination of the regulation of ion channels by specific receptors $(17$, 18). In the present investigation, we examined the hypothesis that trypsin regulates PDEC through PAR-2. Our aims were to $(a)$ determine that trypsin and PAR-2 agonists affect channel activities of PDEC, $(b)$ identify the channels thus regulated, $(c)$ define the signaling pathway mediating PAR-2 effects on PDEC, $(d)$ delimit the apical and/or basolateral expression of functional PAR-2, and (e) localize PAR-2 within the pancreas and PDEC.

\section{Methods}

Chemicals and reagents. Bovine trypsin XII-S (11,900 benzoylarginine ethyl ester [BAEE] units/mg protein) and ovomucoid trypsin inhibitor (III-O, inhibiting 13,000 BAEE units/mg protein) were from Sigma Chemical Co. (St. Louis, Missouri, USA). Indo-1/AM was from Molecular Probes (Eugene, Oregon, USA). Activating peptide (AP, SLIGRL- $\mathrm{NH}_{2}$ ) corresponding to the tethered ligand of mouse PAR-2, and reverse peptide (RP, LRGILS- $\mathrm{NH}_{2}$ ), were synthesized by solid-phase methods and purified by high-pressure liquid chromatography. Analogues of these peptides, highly selective for PAR-1 (AF[PF]RChaCitY$\mathrm{NH}_{2}$ ) or PAR-2 (tc-LIGRLO-NH berg (University of Calgary, Calgary, Alberta, Canada) (19-21). The sources of other reagents have been described (15-18).

Antibodies. Rabbit antibody PAR-2 B5, raised against a fragment of rat PAR-2 $\left({ }^{30}\right.$ GPNSKGR $\downarrow$ SLIGRLDT ${ }^{46}$ P-YGGC, $\downarrow=$ trypsin cleavage site), was a gift from $\mathrm{M}$. Hollenberg and was used at a dilution of 1:500-1:2,000 $(9,13)$. Rabbit antibody PAR-2 C, raised against a fragment of human PAR-2 $\left(\downarrow{ }^{37}\right.$ SLIGKVDGTSHVTGKG $\left.{ }^{53} \mathrm{~V}\right)$, was a gift from C. Derian (R.W. Johnson Pharmaceutical Research Institute, Spring House, Pennsylvania, USA) and was used at $2 \mu \mathrm{g} / \mathrm{ml}$ (22). Mouse monoclonal antibody to von Willebrand factor was from DAKO Corp. (Carpenteria, California, USA) and used at 1:50. Goat anti-rabbit IgG conjugated to FITC and goatanti-mouse IgG conjugated to Texas-Red were from Cappel Research Products (Durham, North Carolina, USA) and Jackson Immuno Research Laboratories Inc. (West Grove, Pennsylvania, USA); they were used at a dilution of 1:200.

PDEC culture. PDEC were isolated from the accessory pancreatic duct of a dog and cultured as described previously (14). The cells used in this report were between passages 9 and 30 .

Efflux studies. Cellular ${ }^{125} \mathrm{I}^{-}$and ${ }^{86} \mathrm{Rb}^{+}$effluxes were measured to study activation of $\mathrm{Cl}^{-}$and $\mathrm{K}^{+}$conductance, as described for T84 cells $(23)$ and extended to PDEC $(15,16)$. In brief, confluent PDEC and supporting membranes were excised, washed in experimental buffer $(140 \mathrm{mM} \mathrm{NaCl}, 4.7 \mathrm{mM} \mathrm{KCl}, 1.2 \mathrm{mM}$ $\mathrm{CaCl}_{2}, 10 \mathrm{mM}$ glucose, $10 \mathrm{mM}$ HEPES, $\mathrm{pH}$ 7.4), and incubated for $45 \mathrm{~min}$ with buffer containing either $\sim 2 \mu \mathrm{Ci} / \mathrm{ml} \mathrm{Na}^{125} \mathrm{I}$ or $\sim 1 \mu \mathrm{Ci} / \mathrm{ml}^{86} \mathrm{RbCl}$. Isotope efflux was measured by sequential addition and removal of $1 \mathrm{ml}$ of isotope-free buffer at 15 -s intervals for $5 \mathrm{~min}$. After a basal period of $1 \mathrm{~min}$, agonists were added to all solutions for $4 \mathrm{~min}$. Inhibitors were added at the beginning of the experiment, except for 1,2-bis(2-aminophenoxy)ethane- $\mathrm{N}, \mathrm{N}, \mathrm{N}^{\prime}, \mathrm{N}^{\prime}$-tetraacetic acid, tetra(acetoxymethyl) ester (BAPTA/AM), which was also added during the ${ }^{125} \mathrm{I}^{-}$loading period. The efflux rate coefficient for a certain time interval was calculated using the formula: $r=\left[\ln \left(R_{1}\right)-\ln \left(R_{2}\right)\right] /\left(\mathrm{t}_{1}-\mathrm{t}_{2}\right)$, where $R_{1}$ and $R_{2}$ are the percent of counts initially loaded remaining in the cells at times $t_{1}$ and $t_{2}$. In certain experiments in which the peak effluxes were compared, we also considered the increase of the efflux rate coefficient above the baseline efflux rate coefficient. The baseline rate coefficient is determined as the lowest efflux rate coefficient immediately before addition of AP or trypsin (15-18).

Ussing chamber studies. Ion transports across confluent PDEC monolayers or across their apical or basolateral membranes were determined in Ussing chambers as described previously $a$

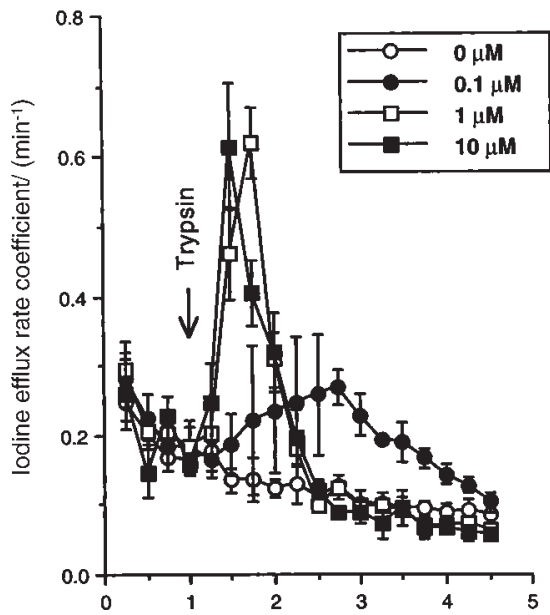

$\boldsymbol{b}$

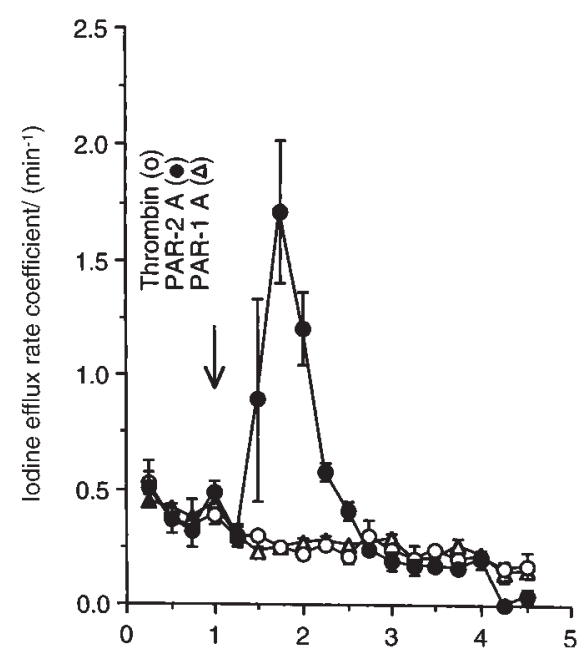

Figure 1

Stimulation of ${ }^{125}$ |- efflux by trypsin. $\left.{ }^{125}\right|^{-}$efflux was monitored as detailed in Methods and the efflux rate coefficient shown (means \pm SEM, $n=3$ ). (a) After $1 \mathrm{~min}$ for baseline determination, trypsin was added at the final concentrations shown. (b) After $1 \mathrm{~min}, 1 \mu \mathrm{M}$ of either thrombin (open circle), the PAR-1 agonist, AF(PF)RChaCitY-NH 2 (PAR-1 A, open circle), or the PAR-2 agonist, tc-LGRLO-NH 2 (PAR-2 A, filled circle), was added. 


\section{Figure 2}

Stimulation of $\left.{ }^{125}\right|^{-}$efflux by AP. $\left.{ }^{125}\right|^{-}$efflux was monitored as detailed in Methods and the efflux rate coefficient shown (means \pm SEM, $n$ =3). (a) After $1 \mathrm{~min}$ for baseline determination, AP was added at the final concentrations shown. (b) After $1 \mathrm{~min}, 1 \mu \mathrm{M}$ of either activating peptide (closed circle) or reversed activating peptide ( $R P$, open square) was added. Control efflux without peptide is indicated by an open circle. (c) After $1 \mathrm{~min}, 1 \mu \mathrm{M}$ AP was added in the absence (open circle) or presence of $500 \mu \mathrm{M}$ NPPB (closed circle) or DIDS (open triangle). (d) After $1 \mathrm{~min}, 1 \mu \mathrm{M}$ AP was added to cells pretreated with $50 \mu \mathrm{M}$ BAPTA/AM (closed circle) or untreated control cells (open circle). AP, activating peptide; BAPTA/AM, 1,2bis(2-aminophenoxy)ethane-N,N, $N^{\prime}, N^{\prime}$ tetraacetic acid, tetra(acetoxymethyl) ester DIDS, 4,4'-diisothiocyanatostilbene-2,2'-disulfonic acid; NPPB, 5-nitro2-(3-phenylpropylamino)benzoic acid.
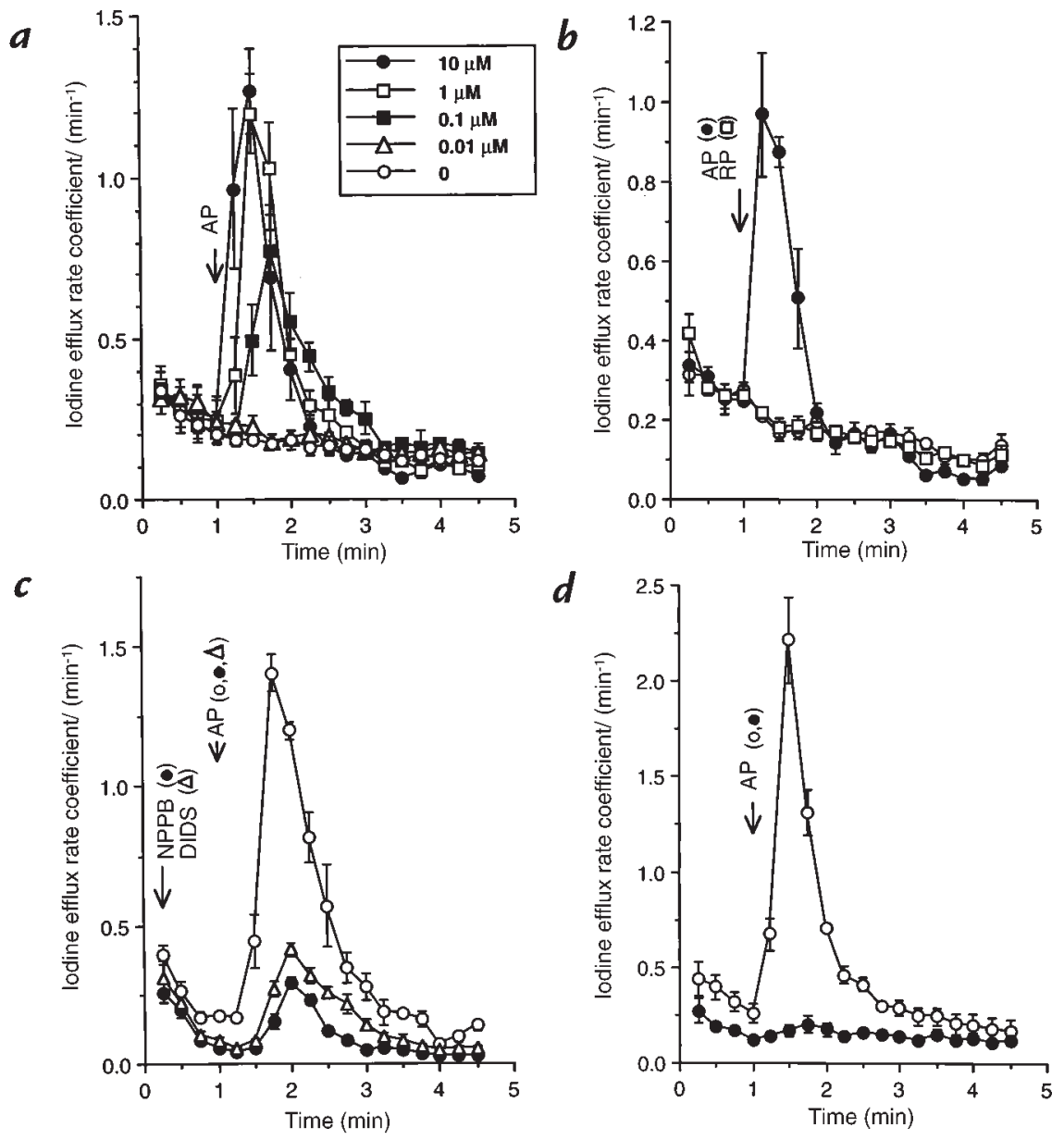

(16-18). To study apical $\mathrm{Cl}^{-}$conductance, the basolateral cell membrane was permeabilized to small monovalent ions with nystatin $(0.36 \mathrm{mg} / \mathrm{ml}$ in the serosal compartment for $\geq 20 \mathrm{~min})$. A $135-\mathrm{mM}$ serosal-to-luminal $\mathrm{Cl}^{-}$gradient was generated using a serosal buffer (135 mM NaCl, $1.2 \mathrm{mM} \mathrm{CaCl}_{2}, 1.2 \mathrm{mM} \mathrm{MgCl}_{2}$, $2.4 \mathrm{mM} \mathrm{K}_{2} \mathrm{HPO}_{4}, 0.6 \mathrm{mM} \mathrm{KH}_{2} \mathrm{PO}_{4}, 10 \mathrm{mM}$ HEPES, $10 \mathrm{mM}$ glucose) and a luminal buffer in which the $\mathrm{NaCl}$ was substituted with Na-gluconate. To study basolateral $\mathrm{K}^{+}$conductance, the apical membrane was permeabilized using nystatin. A 114-mM luminal-to-serosal $\mathrm{K}^{+}$gradient was generated with a luminal buffer of $\left(10 \mathrm{mM} \mathrm{NaCl}, 1.25 \mathrm{mM} \mathrm{CaCl}_{2}, 1 \mathrm{mM} \mathrm{MgCl}_{2}, 118 \mathrm{~K}\right.$ gluconate, $10 \mathrm{mM}$ HEPES, $10 \mathrm{mM}$ glucose, titrated to $\mathrm{pH} 7.4$ with $\mathrm{NaOH}$ ) and a serosal buffer in which the $118 \mathrm{~K}$ gluconate was substituted with $4 \mathrm{~K}$ gluconate and $114 \mathrm{~N}$-methyl-D-glucamine. In the latter case, ouabain $(100 \mu \mathrm{M})$ was used to inhibit the $\mathrm{Na}^{+}, \mathrm{K}^{+}$-ATPase pump and maintain intracellular ATP.

Cytosolic $\mathrm{Ca}^{2+}$ studies. PDEC were cultured to subconfluence on glass coverslips coated with Vitrogen and loaded with $1 \mu \mathrm{M}$ of the membrane-permeant Indo- $1 \mathrm{AM}$ at room temperature for $30 \mathrm{~min}$ and perfused with experimental buffer (solution exchange within $2 \mathrm{~s}$ ). Fluorescence in single cells was detected using an inverted epifluorescence microscope (Diaphot; Nikon, Melville, New York, USA), fitted with a 100-W mercury lamp, and two photon-counting photomultiplier tubes (Hamamatsu H3460-04; Hamamatsu Photonic Systems, Bridgewater, New Jersey, USA). Cells were excited at $365 \mathrm{~nm}$, and emission was measured every $2 \mathrm{~s}$ at 405 and $500 \mathrm{~nm}$. Correction was made for background fluorescence.

Intracellular free $\mathrm{Ca}^{2+}$ concentration $\left(\left[\mathrm{Ca}^{2+}\right]_{\mathrm{i}}\right)$ was calculated as: $\mathrm{K}^{*}(\mathrm{R}-\mathrm{Rmin}) /(\mathrm{Rmax}-\mathrm{R})$, where $\mathrm{R}$ is the ratio of cellular fluorescence at $405 \mathrm{~nm} /$ fluorescence at $500 \mathrm{~nm}$, Rmin the corre- sponding cellular ratio in a $\mathrm{Ca}^{2+}$-free buffer, and $\mathrm{Rmax}$ the ratio obtained with $\mathrm{Ca}^{2+}$-bound dye (25). $\mathrm{K}^{*}$ was calculated using cells perfused with the experimental buffer containing $5 \mu \mathrm{M}$ ionomycin plus either $50 \mathrm{mM}$ EGTA (Rmin), $20 \mathrm{mM} \mathrm{Ca}^{2+}$ (Rmax), or $15 \mathrm{mM} \mathrm{Ca}^{2+}$ and $20 \mathrm{mM} \mathrm{EGTA} \mathrm{(calculated}\left[\mathrm{Ca}^{2+}\right]_{\mathrm{i}}$ was $251 \mathrm{nM}$ ). Values for Rmin, Rmax, and $\mathrm{K}^{*}$ were $0.44,4.46$, and $1770 \mathrm{nM}$, respectively ( $n=8-13$ cells for each measurement).

Immunostaining. Pancreas from an adult dog was fixed in $4 \%$ paraformaldehyde in $100 \mathrm{mM}$ PBS for $48-72 \mathrm{~h}$ at $4^{\circ} \mathrm{C}$ and placed in $25 \%$ sucrose in PBS for $24 \mathrm{~h}$ at $4^{\circ} \mathrm{C}$. Specimens were either $(a)$ embedded in OCT (Miles, Slough, United Kingdom) and 10- $\mu \mathrm{m}$ frozen sections prepared and postfixed in $4 \%$ paraformaldehyde in PBS for 20 min or (b) dehydrated, embedded in paraffin, and sectioned at $5 \mu \mathrm{m}$. PDEC, cultured on filters for 8 days, were fixed in $4 \%$ paraformaldehyde in PBS for $20 \mathrm{~min}$, at $4^{\circ} \mathrm{C}$, dehydrated, embedded in paraffin, and sectioned at $5 \mu \mathrm{m}$. Paraffin sections were deparaffinized in xylene and rehydrated.

Sections were processed to localize PAR-2 by indirect immunofluorescence, as described previously $(9,13)$. In controls, diluted antibodies were preincubated for $24 \mathrm{~h}$ at $4^{\circ} \mathrm{C}$ with $1-100 \mu \mathrm{M}$ of the peptide fragment used for immunization, or nonspecific rabbit IgG were substituted. To localize PAR-2 and endothelial cells simultaneously, slides were concurrently incubated with rabbit polyclonal antibody B5 and mouse monoclonal antibody against von Willebrand factor, followed by secondary antibodies conjugated to contrasting fluorophores. Serial sections of tissues were also stained with hematoxylin and eosin, to assist in identifying pancreatic ducts, acini, and blood vessels. Slides were observed using a Zeiss Axioplan microscope (Carl Zeiss Inc., Thornwood, New York, USA) and an MRC 1000 laser scanning confocal microscope (Bio-Rad Laboratories Inc., 


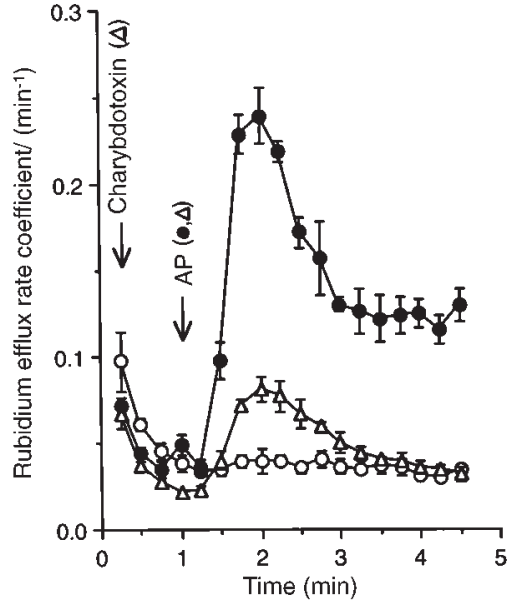

Figure 3

Stimulation of ${ }^{86} \mathrm{Rb}^{+}$efflux by activating peptide. ${ }^{86} \mathrm{Rb}^{+}$efflux was monitored as detailed in Methods and the efflux rate coefficient shown (means $\pm \mathrm{SEM}, n=3$ ). After 1 min for baseline determination, $1 \mu \mathrm{M} \mathrm{AP}$ was added in the presence (open triangle) or absence (closed circle) of 100 $\mathrm{nM}$ charybdotoxin. Control efflux without AP is indicated (open circle).

Hercules, California, USA) (26).

Statistics. Results, based on at least three experiments, were expressed as means and SEM, unless specified otherwise. Statistical significance was determined using unpaired two-tailed Student's $t$ tests.

\section{Results}

Iodide efflux studies. Trypsin activation of ion channels of PDEC was first evaluated. Trypsin stimulated ${ }^{125} \mathrm{I}^{-}$efflux in a concentration-dependent manner, with efflux peak rate coefficients of $0.268 \pm 0.25 / \mathrm{min}$ (peak increase above baseline: $0.085 / \mathrm{min}$ ), $0.620 \pm 0.051 / \mathrm{min}$ (peak increase: $0.436 / \mathrm{min}$ ), and $0.615 \pm 0.089 / \mathrm{min}$ (peak increase: $0.456 / \mathrm{min}$ ) observed, respectively, 105,45 , and $30 \mathrm{sec}-$ onds after the addition of $0.1,1$, and $10 \mu \mathrm{M}$ trypsin (Fig. 1a). Thus, increasing concentrations of trypsin stimulated ${ }^{125} \mathrm{I}^{-}$effluxes with larger peak efflux rate coefficients and of quicker onsets. When trypsin was neutralized for 45 minutes at $37^{\circ} \mathrm{C}$ with ovomucoid trypsin inhibitor

Table 1

Effect of trypsin and AP on $\left[\mathrm{Ca}^{2+}\right]$

\begin{tabular}{|c|c|c|}
\hline Treatment & Basal $\left[\mathrm{Ca}^{2+}\right]_{i}(\mathrm{nM})$ & $\operatorname{Peak}\left[\mathrm{Ca}^{2+}\right]_{i}(\mathrm{nM})$ \\
\hline Trypsin & $52 \pm 11$ & $487 \pm 100^{A}$ \\
\hline Trypsin + charybdotoxin ${ }^{B}$ & $53 \pm 6$ & $715 \pm 99^{A}$ \\
\hline AP & $51 \pm 7$ & $303 \pm 41^{A}$ \\
\hline $\mathrm{AP}+$ charybdotoxin $^{\mathrm{C}}$ & $72 \pm 6$ & $703 \pm 127^{A}$ \\
\hline$A P+D I D S^{B}$ & $62 \pm 14$ & $370 \pm 50^{\mathrm{A}}$ \\
\hline
\end{tabular}

The effects of $1 \mu \mathrm{M}$ trypsin or AP on $\left[\mathrm{Ca}^{2+}\right]_{i}$ of PDEC, in the presence or absence charybdotoxin $(100 \mathrm{nM})$ or DIDS $(500 \mu \mathrm{M})$, were determined as described in Methods. Basal $\left[\mathrm{Ca}^{2+}\right]_{i}$ and peak $\left[\mathrm{Ca}^{2+}\right]_{i}$ following agonist addition are shown (mean \pm SEM). Charybdotoxin and DIDS were added $2 \mathrm{~min}$ before AP or trypsin. When DIDS was used, the results were corrected for its background fluorescence. ASignificant difference between basal $\left[\mathrm{Ca}^{2+}\right]$; and stimulated peak $\left[\mathrm{Ca}^{2+}\right]_{\text {it }}$ at $\boldsymbol{P}<0.05$. Peak $\left[\mathrm{Ca}^{2+}\right]$, stimulated by AP and trypsin were not significantly different $(P>0.1)$, and the peak $\left[\mathrm{Ca}^{2+}\right]_{i}$ stimulated by AP or trypsin was not significantly different in the presence or absence of charybdotoxin or DIDS. ${ }^{B} P>0.1 . C P>0.05$. $P D E C$, pancreatic duct epithelial cell. (4.2-fold excess of inhibitory potential based on estimates of BAEE units), its ability to stimulate ${ }^{125} \mathrm{I}^{-}$efflux was abolished (data not shown), suggesting that its effect was dependent on its enzymatic activity.

Although trypsin is the most effective activator for PAR2 , it also is a weak activator of PAR-1 and PAR-3 and a strong activator of PAR-4 (2-5), the latter highly expressed in the pancreas (4). To evaluate whether the stimulation of ${ }^{125} \mathrm{I}^{-}$efflux by trypsin may be mediated by proteinaseactivated receptors other than PAR-2, we assessed the effect of thrombin, which strongly activates PAR-1, PAR3 , and PAR-4 (2-5). Thrombin $(1 \mu \mathrm{M})$ had no effect on ${ }^{125} \mathrm{I}^{-}$ efflux (Fig. 1b). AF(PF)RChaCitY-NH $\mathrm{N}_{2}$, a selective agonist of PAR-1, at $1 \mu \mathrm{M}$, had no effect on ${ }^{125} \mathrm{I}^{-}$efflux, whereas the same concentration of the PAR-2 agonist, tc-LIGRLO$\mathrm{NH}_{2}$, stimulated a robust response (Fig. 1b). Together, these results suggest that PAR-1, PAR-3, and PAR-4 do not mediate the stimulation of ${ }^{125} \mathrm{I}^{-}$efflux; by exclusion, trypsin most likely acts through PAR-2.

$\mathrm{AP}$, a synthetic activating peptide (SLIGRL-NH $\mathrm{NH}_{2}$ that corresponds to the tethered ligand of PAR-2, directly activates the receptor (6). AP stimulated ${ }^{125} \mathrm{I}^{-}$efflux in a concentration-dependent manner: $0.01 \mu \mathrm{M}$ produced no response, $0.1 \mu \mathrm{M}$ produced an intermediate response, with a peak efflux rate coefficient of $0.775 \pm 0.067 / \mathrm{min}$ (peak increase above baseline: $0.566 / \mathrm{min}$ ), and $1 \mu \mathrm{M}$ and $10 \mu \mathrm{M}$ produced maximal responses with peak efflux rate coefficients of $1.197 \pm 0.122 / \mathrm{min}$ (peak increase: $0.954 / \mathrm{min}$ ) and $1.268 \pm 0.131$ (peak increase: $1.018 / \mathrm{min}$ ), respectively (Fig. 2a). A peptide with the reverse sequence of AP (RP) did not stimulate an increased ${ }^{125} \mathrm{I}^{-}$efflux (Fig. $2 b$ ).

To verify that the increased ${ }^{125} \mathrm{I}^{-}$efflux occurred through activated $\mathrm{Cl}^{-}$conductances, the effect of different inhibitors of $\mathrm{Cl}^{-}$channels was studied. While the control peak efflux rate coefficient produced by $1 \mu \mathrm{M}$ AP was $1.405 \pm 0.066 / \mathrm{min}$ (peak increase above baseline: $1.24 / \mathrm{min}$ ), it was significantly inhibited to $0.292 \pm$ $0.018 / \mathrm{min}$ (peak increase: $0.235 / \mathrm{min}$ ) with $500 \mu \mathrm{M} 5$ nitro-2-(3-phenylpropylamino)benzoic acid (NPPB) and to $0.412 \pm 0.026 / \mathrm{min}$ (peak increase: $0.329 / \mathrm{min}$ ) with $500 \mu \mathrm{M} 4,4^{\prime}$-diisothiocyanatostilbene-2,2'-disulfonic acid (DIDS) $(P<0.001$ compared with control for both inhibitors) (Fig. 2c).

Of the two $\mathrm{Cl}^{-}$channels previously identified on the dog PDEC, the cAMP-activated cystic fibrosis transmembrane conductance regulator (CFTR) and the $\mathrm{Ca}^{2+}$-activated $\mathrm{Cl}^{-}$ channel, only the latter channel was sensitive to DIDS (15). Sensitivity of AP-stimulated ${ }^{125} \mathrm{I}^{-}$to DIDS is consistent with its mediation through the $\mathrm{Ca}^{2+}$-activated $\mathrm{Cl}^{-}$ channel, stimulated by an increased $\left[\mathrm{Ca}^{2+}\right]_{\mathrm{i}}$. This possibility was further verified using BAPTA/AM, a cell-permeant $\mathrm{Ca}^{2+}$ chelator. As shown in Fig. $2 d$, in cells treated with BAPTA/AM, AP no longer increased ${ }^{125} \mathrm{I}^{-}$efflux.

Rubidium efflux studies. Through measurements of ${ }^{86} \mathrm{Rb}^{+}$efflux, we recently observed that PDEC express $\mathrm{Ca}^{2+}$-activated $\mathrm{K}^{+}$channels (16). Should PAR-2 mediate $\left[\mathrm{Ca}^{2+}\right]_{\mathrm{i}}$ mobilization, it may also activate these $\mathrm{K}^{+}$channels. As shown in Fig. 3, $1 \mu \mathrm{M}$ AP stimulated an increased ${ }^{86} \mathrm{Rb}^{+}$efflux, with a peak efflux rate coefficient of $0.239 \pm 0.016 / \mathrm{min}$ (peak increase above baseline: $0.205 / \mathrm{min}, n=3), 1 \mathrm{~min}$ after its addition. This effect was inhibited by $100 \mathrm{nM}$ charybdotoxin, an 
inhibitor of $\mathrm{Ca}^{2+}$-activated $\mathrm{K}^{+}$channels, to a peak efflux rate coefficient of $0.081 \pm 0.007 / \mathrm{min}$ (peak increase: $0.059 / \mathrm{min}, P<0.001$ compared with control).

Intracellular $\mathrm{Ca}^{2+}$ determination. To mediate activation of the $\mathrm{Ca}^{2+}$-activated $\mathrm{Cl}^{-}$and $\mathrm{K}^{+}$channels, PAR-2 action must be coupled to an increased $\left[\mathrm{Ca}^{2+}\right]_{\mathrm{i}}$. This signaling mechanism is also consistent with BAPTA inhibition and observations obtained in other systems (8). The effects of trypsin and AP on $\left[\mathrm{Ca}^{2+}\right]_{\mathrm{i}}$ were determined using Indo-1, a Ca ${ }^{2+}$-sensitive dye. Trypsin $(1 \mu \mathrm{M})$ stimulated a biphasic $\left[\mathrm{Ca}^{2+}\right]_{i}$ response with a sharp increase within the first 4 seconds, followed by a slower increase that was sustained over time (Fig. 4a); $1 \mu \mathrm{M}$ AP stimulated a similar increase in $\left[\mathrm{Ca}^{2+}\right]$, except that the initial sharp response was often blunted. The average peak responses stimulated by AP and trypsin and the lack of inhibition of this response by DIDS and charybdotoxin are shown in Table 1 . In addition, AP was also able to stimulate an increased $\left[\mathrm{Ca}^{2+}\right]_{\mathrm{i}}$ in cells treated with 500 $\mu \mathrm{M}$ NPPB (from a basal concentration of $50 \mathrm{nM}$ to a stimulated concentration of $277 \mathrm{nM}, n=2$ ).

Ussing chamber studies. Because these dog PDEC are polarized and form confluent monolayers with high transepithelial resistance, they were mounted in Ussing chambers to assess PAR-2 expression on their basolateral or apical surface. As shown in Fig. $5 a, 1 \mu \mathrm{M}$ trypsin stimulated an increased short-circuit current (Isc) when added to the serosal compartment, contiguous with the basolateral side of the cell. In contrast, when added to the luminal compartment on the apical side of the cell, trypsin produced no Isc change. Preincubation of trypsin with trypsin inhibitor abolished the ability of trypsin to stimulate an increased Isc (Fig. 5b). Similarly, $1 \mu \mathrm{M}$ AP stimulated an increased Isc only when added to the serosal, but not luminal, compartment of the Ussing chamber (data not shown). Together, these observations suggest that functional PAR-2 is expressed on the basolateral membrane of PDEC. In additional experiments, we also observed that $1 \mu \mathrm{M}$ thrombin did not stimulate an increased Isc when added to either serosal or luminal compartment (Fig. $5 c$ ) and that the PAR-1 agonist, $\mathrm{AF}(\mathrm{PF}) \mathrm{RChaCitY}-\mathrm{NH}_{2}$, stimulated a very modest response compared with the

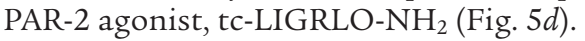

Because we have not yet fully defined the mechanism accounting for the net transepithelial electrogenic ion transport reflected by the Isc, we determined whether AP stimulated apical membrane $\mathrm{Cl}^{-}$conductances and basolateral membrane $\mathrm{K}^{+}$conductances. PDEC were mounted in Ussing chambers, and their basolateral or apical membrane permeabilized with nystatin. To study $\mathrm{Cl}^{-}$ flow through apical $\mathrm{Cl}^{-}$conductances, the basolateral membrane was permeabilized, and a $135-\mathrm{mM}$ serosal-toluminal $\mathrm{Cl}^{-}$gradient was used to drive $\mathrm{Cl}^{-}$flow across the apical membrane. Activation of apical $\mathrm{Cl}^{-}$conductances thus promotes an intra-to-extracellular $\mathrm{Cl}^{-}$flow across the membrane, manifested by an Isc increase. In this system, serosal, but not luminal, addition of $1 \mu \mathrm{M}$ AP stimulated an increased Isc (Fig. 6a), providing electrophysiologic support for AP interaction with basolateral PAR-2 to activate apically located $\mathrm{Cl}^{-}$conductances.

Conversely, to study $\mathrm{K}^{+}$flow through basolateral $\mathrm{K}^{+}$

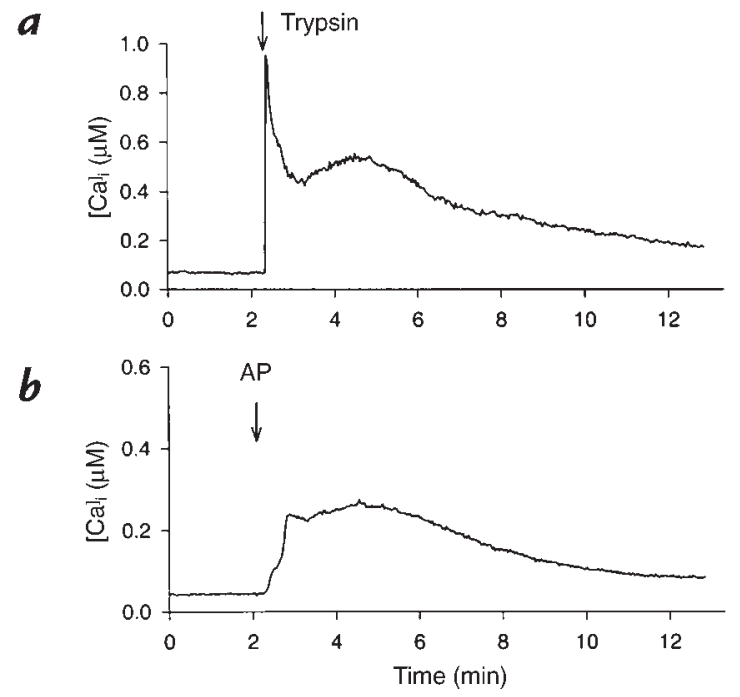

Figure 4

Effects of trypsin and AP on $\left[\mathrm{Ca}^{2+}\right]_{i}$ of PDEC. Pancreatic duct epithelial cells were loaded with Indo-1, and the fluorescences emitted at $405 \mathrm{~nm}$ and $500 \mathrm{~nm}$ while excited at $365 \mathrm{~nm}$ were measured. [ $\left.\mathrm{Ca}^{2+}\right]_{i}$, calculated as described in Methods, was monitored following addition of $1 \mu \mathrm{M}$ trypsin (a) or AP $(\boldsymbol{b})$. The traces shown are representative of six (trypsin) and four (AP) experiments. PDEC, pancreatic duct epithelial cells.

channels, the apical membrane was permeabilized with nystatin, and a $114-\mathrm{mM}$ luminal-to-serosal $\mathrm{K}^{+}$gradient was generated across the basolateral membrane. In this instance, activation of basolateral $\mathrm{K}^{+}$conductances promotes intra-to-extracellular $\mathrm{K}^{+}$flow across the membrane, resulting in an increased Isc. Serosal, but not luminal, addition of AP also stimulated an increased Isc in this setting (Fig. 6b). These findings verify that AP interacts with basolateral PAR-2 to activate basolateral $\mathrm{K}^{+}$conductances.

Immunostaining. We localized PAR-2 by immunofluorescence to provide further evidence for its expression on pancreatic duct cells. In the intact pancreas, immunoreactive PAR-2 was prominent on epithelial cells of the intralobular and interlobular ducts in all regions (Fig. 7a, arrows). The intensity of the staining of the epithelium was similar for intralobular and interlobular ducts. Examination by confocal microscopy indicated that staining of the epithelial cells of pancreatic ducts was often granular in appearance and that these granules were localized in the basal area of the cell (Fig. 7, $c$ and $d$, arrowheads). There was very weak staining of acinar cells in certain regions of the pancreas (not shown). Simultaneous staining with antibodies to PAR-2 and to von Willebrand's factor indicated that PAR-2 was predominantly expressed by epithelial cells of pancreatic ducts rather than endothelial cells of blood vessels, which stained only weakly for PAR-2 (not shown).

In PDEC in culture, PAR-2 immunoreactivity was prominently localized to large vesicles in the basal region of the cells near the nucleus (Fig. 7e, arrows) and in numerous small vesicles that were uniformly distributed throughout the cytoplasm. It was not possible to determine unequivocally whether immunoreactive PAR-2 was present at the basolateral membrane of PDEC, possibly 

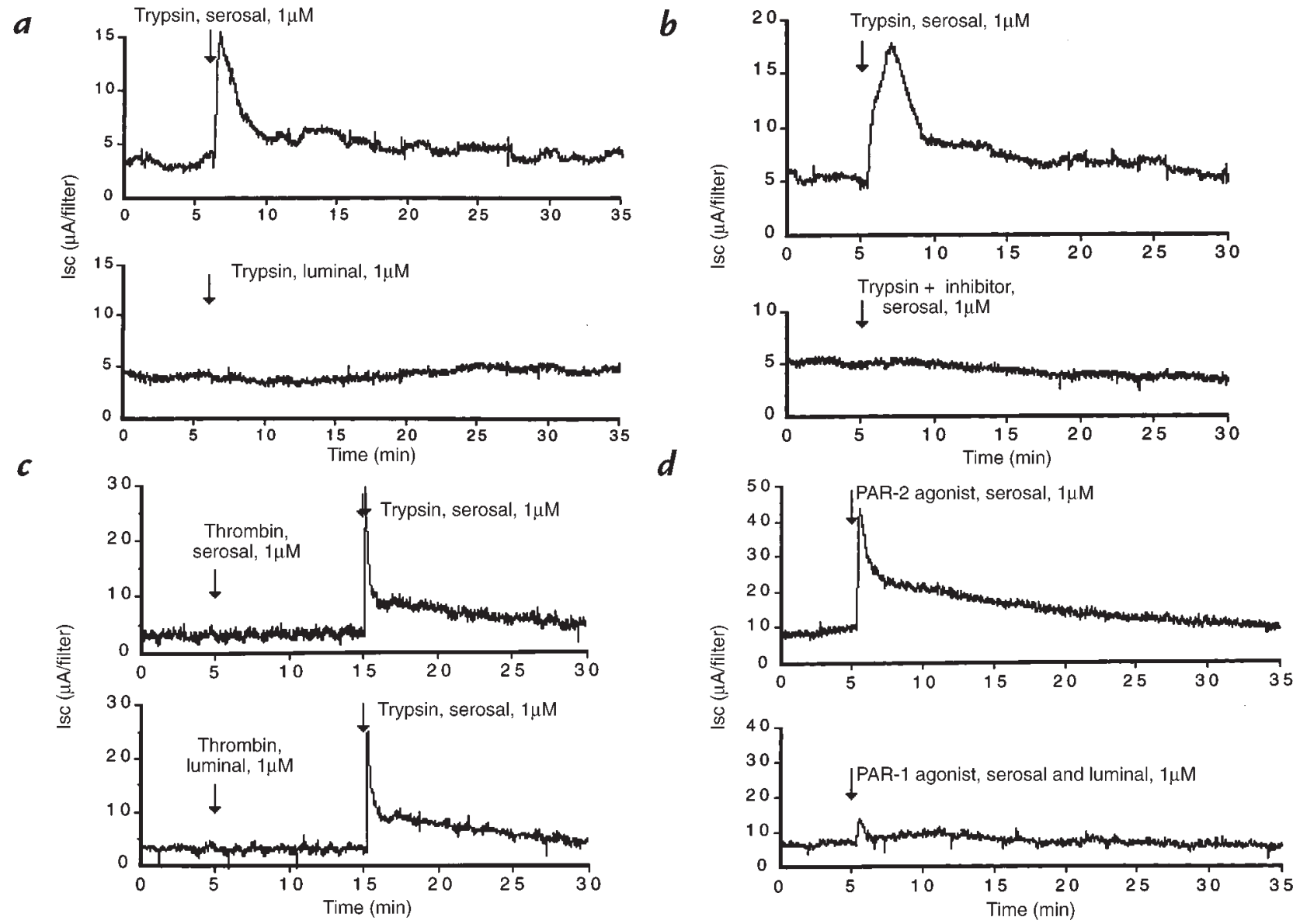

Figure 5

PAR-2 mediated effects on net electrogenic ion transport across PDEC monolayers. PDEC were mounted in Ussing chambers as described in Methods and the Isc $\left(\mu \mathrm{A} /\right.$ filter of $\left.0.95 \mathrm{~cm}^{2}\right)$ shown. The traces in each panel, obtained from monolayers cultured and studied at the same time, are representative of at least three experiments. (a) After $5 \mathrm{~min}$ for baseline determination, trypsin $(1 \mu \mathrm{M}$ ) was added to the serosal (top trace) or luminal compartment (bottom trace). (b) After $5 \mathrm{~min}, 1 \mu \mathrm{M}$ of trypsin (top trace) or trypsin pretreated with trypsin inhibitor (bottom trace) was added to the serosal compartment. (c) After $5 \mathrm{~min}, 1 \mu \mathrm{M}$ thrombin was added to the serosal (top trace) or luminal compartment (bottom trace). After an addition-

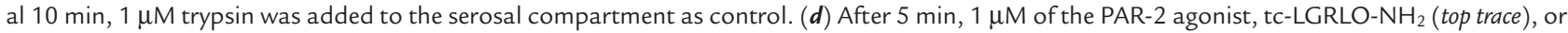

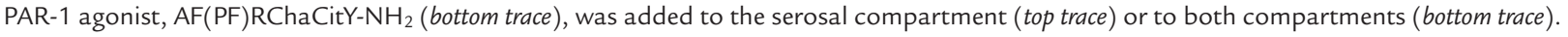

because the close proximity of the filter prevented clear observation of the membranes.

Staining of tissue sections and PDEC was abolished when the primary antibodies were preincubated with the peptides used for immunization (Fig. 7, $b$ and $f$ ) and when the primary antibodies were replaced with an unrelated rabbit IgG (not shown), both indicating specificity. Thus, immunoreactive PAR-2 is expressed by epithelial cells of pancreatic ducts in the intact pancreas, and PDEC continue to express immunoreactive PAR-2 in culture.

\section{Discussion}

PDEC mediate the secretion of fluid and electrolytes by the exocrine pancreas. Trypsin, a proteolytic enzyme secreted by acinar cells, is usually considered to have a role limited to nutrient digestion in the intestinal lumen. In this report, we demonstrate that trypsin can activate ion channels in PDEC by cleaving and triggering PAR-2. Both anatomical and functional evidence indicate that PAR-2 is expressed by PDEC, and our results indicate that trypsin cleaves and triggers PAR- 2 on the basolater- al membrane of these cells. Furthermore, PAR-2 activation increases $\left[\mathrm{Ca}^{2+}\right]_{\mathrm{i}}$ and stimulates $\mathrm{Ca}^{2+}$-activated $\mathrm{Cl}^{-}$ and $\mathrm{K}^{+}$conductances. Thus trypsin, prematurely activated in the inflamed pancreas, may act in a paracrine manner to regulate ion transport by duct cells during pancreatitis. To our knowledge, this is the first direct report that PAR-2 regulates ion channel activity.

Measurements of ${ }^{125} \mathrm{I}^{-}$and ${ }^{86} \mathrm{Rb}^{+}$effluxes to study $\mathrm{Cl}^{-}$ and $\mathrm{K}^{+}$channels, validated with $\mathrm{T} 84$ colonocytes (23), have been used to demonstrate, on cultured PDEC, the expression of the CFTR $\mathrm{Cl}^{-}$channel sensitive to NPPB but resistant to DIDS, a Ca${ }^{2+}$-activated $\mathrm{Cl}^{-}$channel sensitive to both DIDS and NPPB, and a $\mathrm{K}^{+}$channel sensitive to charybdotoxin $(15,16)$. In this report, we observed that trypsin and AP stimulated an ${ }^{125} \mathrm{I}^{-}$efflux that could be inhibited by NPPB and DIDS and a ${ }^{86} \mathrm{Rb}^{+}$efflux that could be inhibited by charybdotoxin. These inhibitory profiles are consistent with the respective mediation of the ${ }^{125} \mathrm{I}^{-}$and ${ }^{86} \mathrm{Rb}^{+}$effluxes by the $\mathrm{Ca}^{2+}$-activated $\mathrm{Cl}^{-}$and $\mathrm{K}^{+}$channels previously identified on these PDEC.

Several observations are consistent with the hypothesis 
that the secretory effects of trypsin are mediated by PAR2. First, we specifically localized immunoreactive PAR-2 to pancreatic duct cells in the intact pancreas and in culture, using antibodies to two different epitopes within the extracellular $\mathrm{NH}_{2}$ terminus in the region of the trypsin cleavage site. Despite the lack of information about the sequence of canine PAR-2, residues around the trypsin cleavage site are highly conserved in mouse, rat, and human $(6,8,27)$. Although we cannot exclude the possibility that the antibodies interact with proteins other than PAR-2, our results suggest that staining of duct epithelial cells is specific for this receptor. Immunoreactive PAR-2 was predominantly detected in intracellular pools in PDEC both in intact tissues and in culture. The precise intracellular location of PAR-2 within PDEC remains to be determined, but PAR-2 is present in prominent Golgi stores in cell lines and in enterocytes, which are important for resensitization of cellular responses to proteases $(8,9,28)$. Second, the stimulatory effect of trypsin on ${ }^{125} \mathrm{I}^{-}$efflux and Isc was abolished after incubation with a trypsin inhibitor. The dependence of trypsin effect on its proteolytic activity is consistent with trypsin action through PAR-2 cleavage. Third, the action of trypsin's was mimicked by a peptide corresponding to the tethered ligand domain of PAR-2. This observation is compatible with the known effects of trypsin, which cleaves PAR-2 to expose a tethered ligand that binds to and activates the cleaved receptor. Fourth, the PAR-2 agonist, tc-LIGRLO-NH${ }_{2}$ (19-21), also stimulated ${ }^{125} \mathrm{I}^{-}$efflux from PDEC. Because trypsin also activates the newly discovered PAR-4 and (albeit weakly) the thrombin receptors PAR-1 and PAR-3, the potential role of these receptors was also examined. The lack of a response to thrombin, which activates PAR-1, PAR-2, and PAR-4, and the lack of

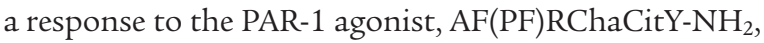
exclude a secretory role for these receptors. Although these receptors may still be expressed on PDEC, they do not mediate the secretory effects of trypsin.
Our results suggest that the tethered ligand domain of canine PAR-2 may be similar to rodent and human PAR2 because mouse and rat AP (SLIGRL-NH $\mathrm{N}_{2}$ ) was able to activate PAR-2 in dog PDEC. Of note, in dog PDEC, PAR-2 was activated with concentrations of trypsin and $\mathrm{AP}$ as low as $0.1 \mu \mathrm{M}$. In previous studies, the $\mathrm{EC}_{50} \mathrm{~s}$ of trypsin and AP for the rat PAR-2 were, respectively, 25 $\mathrm{nM}$ and $17 \mu \mathrm{M}$; for the human PAR-2, the corresponding $\mathrm{EC}_{50} \mathrm{~s}$ were $2.3 \mathrm{nM}$ and $18 \mu \mathrm{M}$ (8). These different potencies may reflect slight interspecies differences of PAR-2 or the different biologic responses evaluated.

Confluent PDEC monolayers display transepithelial electrical resistance adequate for electrophysiologic studies. Indeed, using intact PDEC monolayers in Ussing chambers, we defined the polar distributions of the histamine $\mathrm{H}_{1}$ and purinergic $\mathrm{P} 2 \mathrm{Y}_{2}$ receptors on PDEC (17, $18)$; with permeabilized PDEC, we verified the presence of apical $\mathrm{Cl}^{-}$and basolateral $\mathrm{K}^{+}$conductances $(16,17)$. In the present investigation, we studied basolaterally permeabilized cells subject to a $\mathrm{Cl}^{-}$gradient to show that PAR-2 stimulates apical $\mathrm{Cl}^{-}$conductances. Similarly, we use apically permeabilized cells subject to a $\mathrm{K}^{+}$gradient to verify that PAR- 2 stimulates basolateral $\mathrm{K}^{+}$conductances. In addition, with intact PDEC monolayers, the serosal, but not luminal, addition of trypsin and AP stimulated an increased Isc, reflecting a net electrogenic ion transport. Consistent with the efflux studies, this effect of trypsin was inhibited by trypsin inhibitor, was reproduced by AP and the PAR-2 agonist, tc-LGRLO-NH $\mathrm{N}_{2}$, and was not reproduced with thrombin or the PAR-1 agonist, $\mathrm{AF}(\mathrm{PF}) \mathrm{RChaCitY}-\mathrm{NH}_{2}$. In addition to confirming that trypsin interacts with PAR-2 in PDEC, these results provide functional evidence for localization of PAR-2 at the basolateral membrane of PDEC, as the effects of trypsin and AP were observed only with application to the serosal surface. At the present time, we have not determined all the component ion transport pathways on PDEC that contribute to the Isc generated by intact monolayers. It is $a$
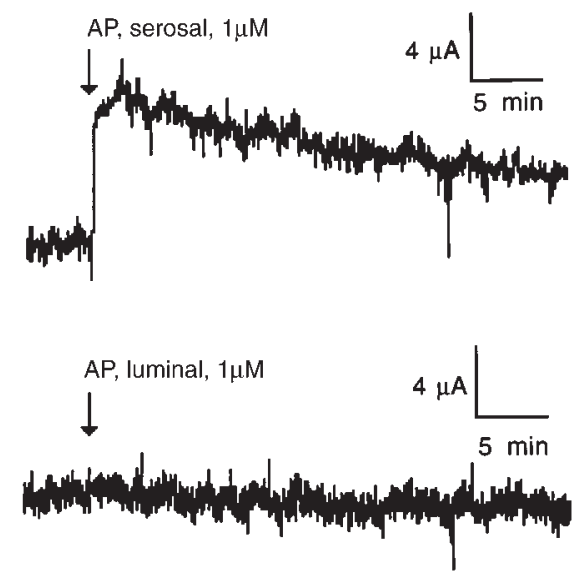

$\boldsymbol{b}$
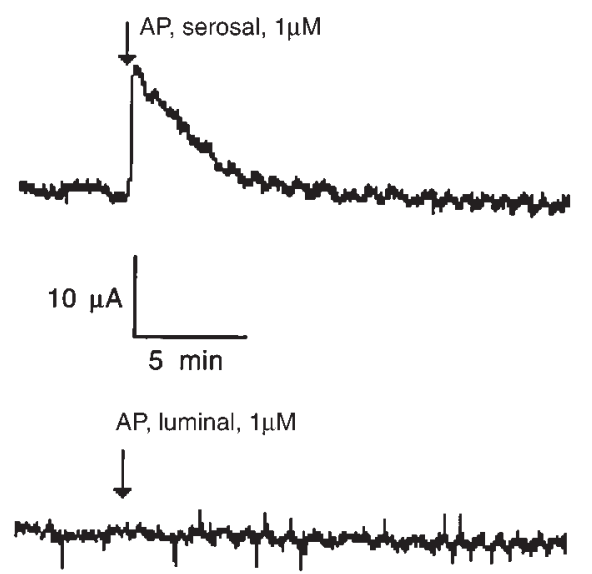

Figure 6

Effect of AP on permeabilized PDEC mounted in Ussing chambers. PDEC were mounted in Ussing chambers and either apical or basolateral membrane permeabilized with nystatin. The traces shown in each panel, obtained from monolayers cultured and studied at the same time, are representative of at least three experiments. (a) The basolateral membrane was permeabilized and a 135 -mM serosal-to-luminal $\mathrm{Cl}^{-}$gradient maintained. The Isc, shown on the ordinate $\left(\mu \mathrm{A} /\right.$ filter of $\left.0.95 \mathrm{~cm}^{2}\right)$, reflects the effect of serosal (top trace) or luminal (bottom trace) addition of $1 \mu \mathrm{M} \mathrm{AP}$ on apical membrane $\mathrm{Cl}^{-}$conductances. (b) The apical membrane was permeabilized and a 114-mM luminal-to-serosal $\mathrm{K}^{+}$gradient maintained. The Isc, shown on the ordinate ( $\mu \mathrm{A} /$ filter of $0.95 \mathrm{~cm}^{2}$ ), reflects the effect of serosal (top trace) or luminal (bottom trace) addition of $1 \mu \mathrm{M}$ AP on basolateral membrane $\mathrm{K}^{+}$conductances. 


\section{Figure 7}

Localization of PAR-2 in PDEC by immunofluorescence. $(\boldsymbol{a}-\boldsymbol{d})$ PAR-2 localization in sections of the body of the intact pancreas using antibody PAR-2 B5. Arrows in a identify intensely stained PDEC. Arrowheads in $c$ and $d$ show granular staining in the basal area of the cells. Asterisk denotes the lumen of the pancreatic ducts. ( $\boldsymbol{e}$ and $\boldsymbol{f}$ ) PAR-2 localization in sections of PDEC grown on Transwell filters using antibody PAR-2 C. The arrows in $e$ indicate the prominent intracellular pools of PAR- 2 in the basolateral region of the cells. Stars indicate the filter. $b$ and $f$ are controls in which the antibodies were preabsorbed with the receptor fragments that were used for immunization. Each image is a sum of three to four optical sections cut at intervals of $0.5-0.7 \mu \mathrm{m}$. Bar, $50 \mu \mathrm{m}$ in $a ; 20$ $\mu \mathrm{m}$ in $b$ and $c ; 28 \mu \mathrm{m}$ in $d ; 13 \mu \mathrm{m}$ in $e$ and $f$.
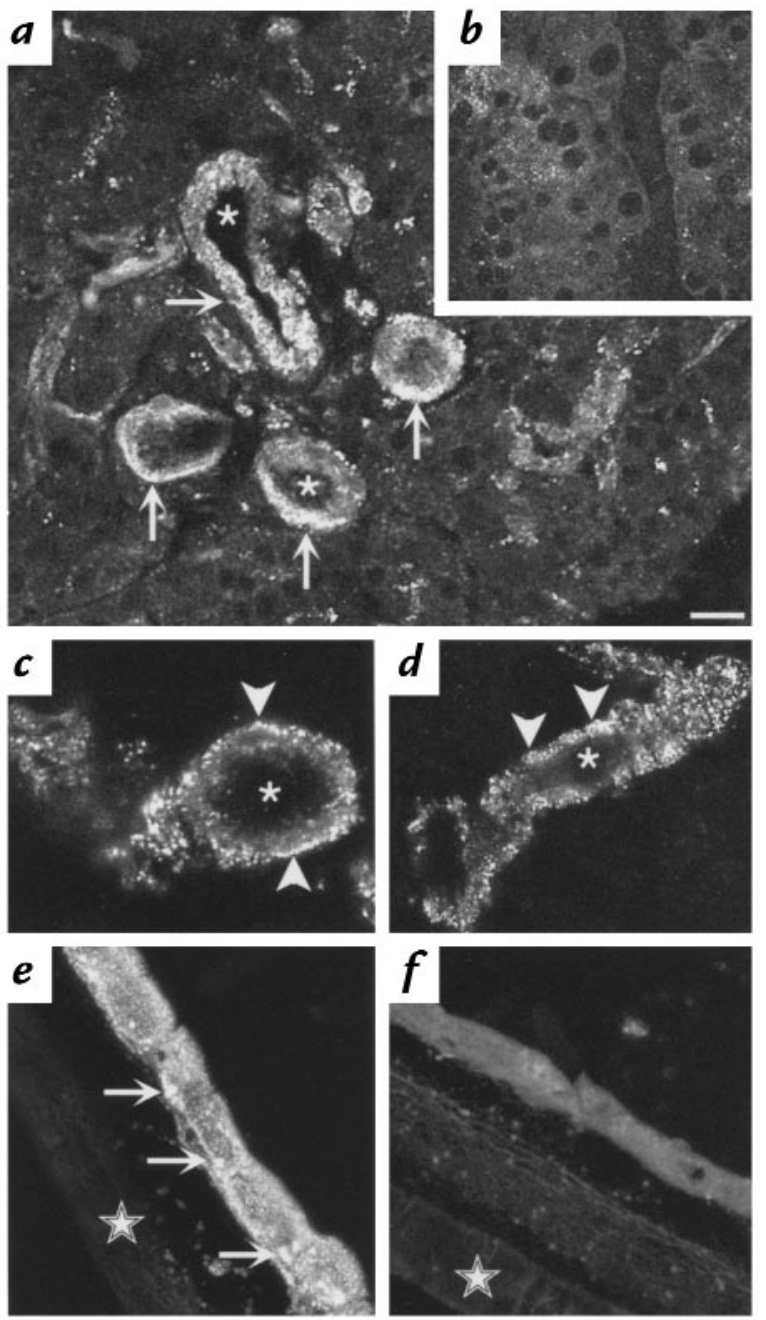

have additional interactions with PDEC that are not mediated through PAR-2.

Under normal circumstances, it is unlikely that pancreatic trypsin cleaves PAR-2 at the serosal membrane of duct epithelial cells. Although a small amount of trypsinogen is normally activated within the pancreas, trypsinogen is mainly activated in the intestinal lumen by enterokinase. Furthermore, pancreatic juice is contained within the duct lumen. However, the array of proteases that trigger PAR-2 remains to be clarified, and it is possible that trypsinlike proteases from the vasculature and interstitium could cleave serosal PAR-2.

Interaction between trypsin and pancreatic ductal PAR2 may occur in certain pathologic states. A fraction of trypsinogen is prematurely autoactivated to trypsin within pancreatic acini under normal conditions; defective neutralization of this trypsin is the cause of hereditary pancreatitis (12). Trypsin is also prematurely activated when acinar cell function is impaired, such as in inflammation $(10,29,30)$. Trypsin produced in these circumstances may leak into the interstitium from damaged acinar cells and cleave PAR-2 at the basal membrane of PDEC. The resulting increased PDEC secretion may flush toxic components from the inflamed pancreas and, thus, be of benefit.

Further support for a role of PAR-2 in inflammation comes from the observation that PAR-2 agonists strong- 
ly stimulate release of arachidonic acid and secretion of prostaglandins from enterocytes (9) and induce expression of cyclooxygenase 2 (Bunnett, N.W., unpublished observations), which generates proinflammatory and mitogenic eicosamoids. Furthermore, PAR-2 is upregulated in human umbilical vein and endothelial cells after stimulation with proinflammatory mediators such as tumor necrosis factor- $\alpha$, interleukin- $1 \alpha$, and bacterial lipopolysaccharide (31). Besides trypsin, tryptase also activates PAR-2 $(7,13)$. Mast cells are present in both normal and inflamed pancreatic tissue (Nguyen, T.D., et al., unpublished observations). It is tempting to postulate that these mast cells may also regulate PDEC ion transport through tryptase release and PAR-2 activation.

In conclusion, this report describes a novel pathway for the regulation of ion transport in PDEC. Besides illustrating the utility of the cultured dog PDEC as a model for ductal secretion, these findings may have important implications for pancreatic pathophysiology.

\section{Acknowledgments}

The authors thank Sum Lee (University of Washington, Seattle, Washington, USA) for his advice on culture and characterization of PDEC, Phillip Ursell (University of California, San Francisco, California, USA) for help with interpreting staining of the pancreas, Rix Kuester (Veterans Affairs Puget Sound Health Care System, Seattle, Washington, USA) for harvesting dog pancreas, and M. Hollenberg and C. Derian for gifts of antibodies and PAR agonists. This research was supported by funds from the Cystic Fibrosis Foundation (to T.D. Nguyen), the Department of Veterans Affairs (to T.D. Nguyen), the National Institute of Arthritis, Diabetes, Digestive and Kidney Diseases (to N.W. Bunnett), and the Crohn's and Colitis Foundation (to N.W. Bunnett). C. Okolo is funded through National Institutes of Health (NIH) GI Training Grant DK-07742, and D.S. Koh is funded by NIH grant NS08174 to Bertil Hille.

1. Dery, O., Corvera, C.U., Steinhoff, M., and Bunnett, N.W. 1998. Proteinase-activated receptors: novel mechanisms of signaling by serine proteases. Am. J. Physiol. 274:C1429-1452.

2. Vu, T.-K.H., Hung, D.T., Wheaton, V.I., and Coughlin, S.R. 1991. Molecular cloning of a functional thrombin receptor reveals a novel proteolytic mechanism of receptor activation. Cell. 64:1057-1068.

3. Ishihara, H., et al. 1997. Protease-activated receptor 3 is a second thrombin receptor in humans. Nature. 386:502-506.

4. Xu, W.-F., et al. 1998. Cloning and characterization of human proteaseactivated receptor 4. Proc. Natl. Acad. Sci. USA. 95:6642-6646.

5. Kahn, M.L., et al. 1998. A dual thrombin receptor system for platelet activation. Nature. 394:690-694.

6. Nystedt, S., Emilsson, K., Wahlestedt, C., and Sundelin, J. 1994. Molecular cloning of a potential proteinase activated receptor. Proc. Natl. Acad. Sci. USA. 91:9208-9212.

7. Molino, M., et al. 1997. Interactions of mast cell tryptase with thrombin receptors and PAR-2. J. Biol. Chem. 272:4043-4049.

8. Böhm, S.K., et al. 1996. Molecular cloning, expression and potential func- tions of the human proteinase-activated receptor-2. Biochem. J. 314:1009-1016

9. Kong, W., et al. 1997. Luminal trypsin may regulate enterocytes through proteinase-activated receptor 2. Proc. Natl. Acad. Sci. USA. 94:8884-8889.

10. Hofbauer, B., et al. 1998. Intra-acinar cell activation of trypsinogen during caerulein-induced pancreatitis in rats. Am. J. Physiol. 275:G352-G362.

11. Gorry, M.C., et al. 1997. Mutations in the cationic trypsinogen gene are associated with recurrent acute and chronic pancreatitis. Gastroenterology. 113:1063-1068.

12. Whitcomb, D.C., et al. 1996. Hereditary pancreatitis is caused by a mutation in the cationic trypsinogen gene. Nat. Genet. 14:141-145.

13. Corvera, C.U., et al. 1997. Mast cell tryptase regulates colonic myocytes through proteinase-activated receptor-2. J. Clin Invest. 100:1383-1393.

14. Oda, D., et al. 1996. Dog pancreatic duct epithelial cells: long-term culture and characterization. Am. J. Pathol. 148:977-985.

15. Nguyen, T.D., et al. 1997. Characterization of two distinct chloride channels in cultured dog pancreatic duct epithelial cells. Am. J. Physiol. 272:G172-G180.

16. Nguyen, T.D., and Moody, M.W. 1998. Calcium-activated potassium conductances on cultured non-transformed dog pancreatic duct epithelial cells. Pancreas. 17:348-358.

17. Nguyen, T.D., Moody, M.W., Savard, C.E., and Lee, S.P. 1998. Secretory effects of ATP on non-transformed dog pancreatic duct epithelial cells. Am. J. Physiol. 275:G104-G113.

18. Nguyen, T.D., Okolo, C., and Moody, M.W. 1998. Histamine stimulates secretion by non-transformed pancreatic duct epithelial cells. Am. J. Physiol. 275:G76-G84.

19. Hollenberg, M.D., Saifeddine, M., al-Ani, B., and Kawabata, A. 1997. Proteinase-activated receptors: structural requirements for activity, receptor cross-reactivity, and receptor selectivity of receptor-activating peptides. Can. J. Physiol. Pharmacol. 75:832-841.

20. Roy, S.S., Saifeddine, M., Loutzenhiser, R., Triggle, C.R., and Hollenberg, M.D. 1998. Dual endothelium-dependent vascular activities of proteinase-activated receptor-2-activating peptides: evidence for receptor heterogeneity. Br. J. Pharmacol. 123:1434-1440.

21. Vergnolle, N., et al. 1998. Proteinase-activated receptor 2 (PAR2)-activating peptides: identification of a receptor distinct from PAR2 that regulates intestinal transport. Proc. Natl. Acad. Sci. USA. 95:7766-7771.

22. D'Andrea, M., et al. 1998. Characterization of proteases activated receptor2 immunoreactivity in normal human tissues. J. Histochem. Cytochem. 46:1-8.

23. Venglarik, C.J., Bridges, R.J., and Frizzell, R.A. 1990. A simple assay for agonist-regulated $\mathrm{Cl}$ and $\mathrm{K}$ conductances in salt-secreting epithelial cells. Am. J. Physiol. 259:C358-C364.

24. Nguyen, T.D., and Canada, A.T. 1994. Modulation of human colonic T84 cell secretion by hydrogen peroxide. Biochem. Pharmacol. 47:403-410.

25. Grynkiewicz, G., Peonie, M., and Tsien, R.Y. 1985. A new generation of $\mathrm{Ca}^{2+}$ indicators with greatly improved fluorescence properties. J. Biol. Chem. 260:3440-3450

26. Grady, E.F., et al. 1996. Endocytosis and recycling of NK1 tachykinin receptors in enteric neurons. Neuroscience. 16:1239-1254.

27. Saifeddine, M., Al-Ani, B., Chen, C., Wang, L., and Hollenberg, M. 1996. Rat proteinase-activated receptor-2 (PAR-2): cDNA sequence and activity of receptor-derived peptides and in gastric and vascular tissue. $\mathrm{Br}$. J. Pharm. 118:521-530.

28. Böhm, S.K., et al. 1996. Mechanisms of desensitization and resensitization of proteinase-activated receptor-2. J. Biol. Chem. 271:22003-22016.

29. Yamaguchi, H., Kimura, T., Mimura, K., and Nawata, H. 1989. Activation of proteases in cerulein-induced pancreatitis. Pancreas. 4:565-571.

30. Geokas, M.C., and Rinderknecht, H. 1974. Free proteolytic enzymes in pancreatic juice of patients with acute pancreatitis. Am. J. Dig. Dis. 19.591-598.

31. Nystedt, S., Ramakrishnan, V., and Sundelin, J. 1996. The proteinaseactivated receptor 2 is induced by inflammatory mediators in human endothelial cells. Comparison with the thrombin receptor. J. Biol. Chem. 271:14910-14915. 